\title{
Perilaku Makan Menyimpang pada Remaja di Jakarta
}

\author{
Trulyana Tantiani* Ahmad Syafiq**
}

\begin{abstract}
Abstrak
Salah satu transisi gaya hidup yang terjadi adalah perubahan perilaku makan yang paling berdampak pada kaum perempuan untuk terlihat cantik dengen berdiet berlebihan yang menjurus pada Perilaku Makan Menyimpang (PMM). Tujuan dari penelitian ini adalah mengetahui penyebab, mekanisme, dan proses terjadinya PMM dari persepsi penderita. Desain penelitian yang digunakan adalah kualitatif dan kuantitatif. Penelitian kualitatif dilakukan pada 3 informan yang pernah mengalami PMM. Penelitian kuantitatif, dilakukan pada 397 responden yang belum mengalami PMM. Waktu pengambilan data adalah bulan Mei-Juni 2007 dengan menggunakan metode wawancara mendalam untuk penelitian kualitatif dan wawancara terstruktur menggunakan kuesioner dari Sarafino dari Stice untuk penelitian kuantitatif. Studi kualitatif menemukan bahwa semua informan bermasalah dengan anggota keluarganya, terdapat pengaruh pola asuh keluarga yang cukup besar, memiliki citra tubuh dan konsep diri yang terdistorsi, dan berada di lingkungan yang tidak mendukung orang gemuk. Hasil penelitian kuantitatif menemukan prevalensi PMM yang terjadi di Jakarta dengan kuasioner Sarafino adalah 37,3\% dan prevalensi anoreksia nervosa dengan kuesioneri Stice adalah $11,6 \%$ dan prevalensi kecenderungan bulimia nervosa adalah $27 \%$.
\end{abstract}

Kata kunci : Perilaku makan menyimpang, anoreksia nervosa, bulimia nervosa

\begin{abstract}
One of the life style changes that occur recently is related to eating behavior that affect mostly women because of the desire to look beautiful with a thin and tall body. One way to achieve this figure is to strictly go on dieting which could lead to eating disorders. The objective of this research is to understand the cause, mechanism, and process of eating disorders. The methods in this research are both qualitative and quantitative. The subjects of the qualitative research are three persons who are willing to be the subject and have a past history of eating disorders. The quantitative subjects are 397 respondents that have not been diagnosed with eating disorders. The research was held at May-June 2007. The information are gathered through in-depth interview for the qualitative research and by through self report questionnaire for the quantitative research. The result from qualitative research shows that all of the subjects have problems with their family, the parenting practice have a big influence in their life, they also have a distorted body image and poor self-concept, and they are living in an environment that have a negative behavior towards overweight problems. The quantitative research shows that using Sarafino questionnaire, there are $37.3 \%$ adolescents who have a tendency toward eating disorders. Using the Stice and Telch questionnaire, there are $11.6 \%$ adolescents that have a tendency towards anorexia nervosa, and $27.0 \%$ adolescents that have a tendency towards bulimia nervosa.
\end{abstract}

Key words : Eating disorder, anorexia nervosa, bulimia nervosa

*Peneliti Pusat Kajian Gizi dan Kesehatan FKM UI, Gd. F Lt. 2 Fakultas Kesehatan Masyarakat Universitas Indonesia, Kampus Baru UI Depok 16424 (e-mail : sochandaidai@yahoo.com) **Staf Pengajar Departemen Gizi Kesehatan Masyarakat FKM UI, Gd. F Lt. 2 Fakultas Kesehatan Masyarakat Universitas Indonesia, Kampus Baru UI Depok 16424 (e-mail : asq69@yahoo.co.id) 
Salah satu transisi gaya hidup yang terjadi adalah perubahan perilaku makan yang paling berdampak terutama pada kaum perempuan, untuk terlihat cantik dan menarik dan umumnya perempuan mendeskripsikan cantik dan menarik dengan memiliki tubuh yang kurus dan tinggi. ${ }^{1}$ Hal ini, didukung oleh Holmes, ${ }^{2}$ yang menyatakan tren pakaian pada milenium baru ini yang seakan menuntut perempuan untuk memiliki postur tubuh yang kurus dan tinggi. Untuk dapat memiliki tubuh yang kurus, kaum perempuan mulai melakukan berbagai upaya yang salah satunya adalah dengan berdiet. ${ }^{3}$ Weiss menyatakan, mereka yang beruntung memiliki metabolisme tubuh yang baik akan dapat menerapkan metode yang ditawarkan tadi dengan baik dan dengan hasil yang memuaskan tapi bagi mereka yang tidak dikaruniai kemampuan tersebut, metode yang ditawarkan hampir tidak pernah berhasil. Mereka yang tidak berhasil inilah yang mulai putus asa dan mulai melakukan perubahan perilaku makan secara menyimpang.

Perilaku Makan Menyimpang (PMM) masih sering dianggap sebagai sindrom yang terikat dengan budaya, yaitu bahwa hanya dialami oleh masyarakat negara barat karena selama ini laporan mengenai PMM hanya berasal dari negara barat. ${ }^{4}$ Padahal beberapa tahun belakangan ini PMM juga mulai terjadi pada masyarakat Asia, terutama dengan makin gencarnya pemasaran produkproduk kecantikan dan pakaian-pakaian bergaya luar negeri yang menjual kecantikan ala barat pada pasar Asia. ${ }^{4}$ Menurut Efron, ${ }^{5}$ dalam jangka waktu 5 tahun belakangan ini, gejala PMM mulai menyebar pada perempuan dengan berbagai macam latar belakang dan keadaan sosial ekonomi di Korea, Hongkong, dan Singapura. Beberapa kasus, walau dalam jumlah yang kecil, juga mulai dilaporkan terjadi di Taipei, Beijing dan Shanghai. Bahkan pada negara dengan keadaan sosial ekonomi yang rendah seperti Filipina, India dan Pakistan. ${ }^{5}$

Ada beberapa tipe dari PMM ini. Dua tipe yang paling menonjol adalah anoreksia nervosa dan bulimia nervosa. Satu tipe lainnya yaitu perilaku makan binge. Tipe ini belum dapat disebut sebagai diagnosis psikiatris formal, tapi telah banyak yang menyarankan untuk dimasukkan sebagai salah satu kategori terbesar dari PMM.2 Menurut Diagnostic and Statistical Manual of Mental Disorders (DSM-IV) kriteria anoreksia nervosa adalah penolakan untuk mempertahankan berat badan normal minimal. Sedangkan Bulimia Nervosa dikriteriakan sebagai pengulangan episode binge eating diikuti dengan tindakan kompensasi seperti sengaja muntah, menggunakan laksatif, diuretik, atau obat lainnya, puasa atau olahraga berlebihan. ${ }^{6}$

Di Indonesia belum terlihat ada data tertulis yang dapat menunjukkan prevalensi penderita PMM, baik dari rumah sakit maupun klinik kesehatan di Jakarta. Padahal perilaku makan remaja di perkotaan semakin menjurus ke arah pola makan yang tidak sehat. Faktor-faktor yang memungkinkan terjadinya PMM juga semakin meningkat, sehingga tidak tertutup kemungkinan masalah penyimpangan pola makan ini akan terjadi di Indonesia.

Tujuan utama dilakukannya penelitian ini adalah untuk mengetahui penyebab, mekanisme, dan proses terjadinya PMM dari persepsi penderita dan juga untuk mengetahui gambaran prevalensi kecenderungan PMM pada remaja sekolah di Jakarta, serta melihat gambaran kecenderungan PMM berdasarkan jenis kelamin, IMT, etnis dan usia.

\section{Metode}

Penelitian ini menggunakan desain penelitian kualitatif dan kuantitatif. Kedua penelitian ini mengambil lokasi di Jakarta selama bulan Mei sampai Juni 2007. Penelitian kualitatif dilakukan pada 3 orang subjek penelitian kualitatif (selanjutnya disebut sebagai informan) yang pernah dan/atau sedang menderita PMM untuk mendapatkan informasi utama pada penelitian kualitatif serta informan tambahan seorang dokter dan psikolog untuk mendapatkan informasi tambahan dalam triangulasi sumber. Subjek penelitian kuantitatif (selanjutnya disebut sebagai responden) adalah 397 siswa-siswi SMP dan SMA berusia antara 11-18 tahun yang belum terdeteksi mengalami PMM. Para siswa ini berasal dari keluarga dengan keadaan sosial ekonomi menengah ke atas.

Penelitian kualitatif dilakukan dengan wawancara mendalam. Wawancara mendalam yang dilakukan pada penelitian ini mengambil materi mengenai apa saja yang dapat menyebabkan informan melakukan PMM. Beberapa penyebab yang diperkirakan oleh peneliti berdasarkan studi-studi terdahulu yang dilakukan oleh Logue, ${ }^{1}$ Krummel, ${ }^{7}$ dan McComb, ${ }^{8}$ adalah latar belakang etnis informan, kebiasaan makan keluarga, usia dan jenis kelamin informan, pengaruh citra tubuh dan konsep diri, stress, pengaruh media massa, adanya masalah keluarga, adanya pengalaman pelecehan seksual di masa lalu, adanya anggota keluarga lain yang bermasalah dengan berat badan, adanya faktor sosial ekonomi, sosial budaya, genetik, teman sebaya, pekerjaan, ketakutan menjadi dewasa, acuan makanan, tren makanan dan pola asuh keluarga.

Metode yang digunakan pada penelitian kuantitatif adalah metode cross-sectional karena tidak membutuhkan identitas diri secara spesifik dan terjaminnya kerahasiaan, mengingat masalah PMM adalah masalah yang sensitif. Cara pengambilan data adalah dengan menyebarkan kuesioner yang diisi sendiri oleh para responden. Kuesioner yang diisi adalah kuesioner yang dapat melihat kecenderungan mereka untuk mengembangkan PMM. Kuesioner tersebut diadaptasi dari Eric Stice dan Christy F. Telch, ${ }^{9}$ dan Sarafino. ${ }^{10}$ 
Tahapan pengumpulan informan penelitian kualitatif adalah sebagai berikut. Pertama adalah pencarian informan dengan menanyakan kenalan peneliti apakah ada yang mengenal orang yang penah atau sedang mengalami PMM. Kedua adalah pencarian informan yang dilakukan dengan mencari orang yang memang mengalami PMM melalui penyebaran informasi melalui beberapa mailing-list yang memiliki anggota dengan usia antara 13-35 tahun. Ketiga adalah dengan pencarian informan pada beberapa rumah sakit, pusat kebugaran, lembaga penelitian, dan agensi model di Jakarta. Keempat adalah dengan melakukan pendekatan terhadap informan untuk menjalin hubungan baik dan memperoleh kepercayaan dari informan. Kelima adalah mencari informan tambahan yaitu seorang dokter untuk melihat masalah PMM dari sisi medis dan seorang psikolog untuk melihat masalah PMM dari sisi psikologis. Jumlah total informan yang berhasil diperoleh pada peneltian kualitatif ini adalah sebesar 3 informan utama dan 2 informan pembantu untuk keperluan triangulasi sumber. Keenam adalah melakukan wawancara dengan para informan yaitu wawancara untuk menggali informasi untuk memahami pandangan, kepercayaan, pengalaman, dan pengetahuan informan mengenai suatu hal secara utuh. Dalam membantu pengambilan data ini hasil wawancara direkam untuk informan yang bersedia direkam dengan menggunakan alat perekam suara. Setelah itu informasi yang diperoleh diolah dengan membuat matriks dan membandingkan hasilnya dengan teori yang ada.

Beberapa informan yang awalnya sudah menyatakan kesediaan untuk diwawancara, mengundurkan diri karena merasa malu. Hal ini diatasi dengan mempersempit waktu dari pengenalan peneliti dengan informan kualitatif dengan waktu pengambilan data sebenarnya. Peneliti juga mengupayakan pencarian informan kualitatif lain pada informan kualitatif yang masih menolak. Kesulitan lain adalah wawancara karena masalah tempat dan waktu yang tidak memadai. Hal ini diatasi dengan memilih tempat dan waktu yang nyaman dan memungkinkan dilakukannya wawancara dengan lebih mendalam.

Pada penelitian kuantitatif, setelah memperoleh sekolah yang ingin diteliti, kemudian dilakukan pemilihan sampel dengan cara pertama memilih responden secara acak dari kelas-kelas yang ada. Kemudian diperoleh hasil responden dari SMP A sebanyak 104 orang, SMA B sebanyak 169 orang dan SMA C sebanyak 124 orang. Setelah itu para responden diminta untuk mengisi sendiri kuesioner yang dibagikan dan mengembalikannya setelah selesai. Analisis pada penelitian kuantitatif ini dilakukan dengan menggunakan program komputer baik untuk analisis univariat maupun bivariat.

\section{Hasil \\ Studi Kualitatif}

Penderita PMM yang menjadi informan pada penelitian ini adalah sebanyak 3 orang. (Lihat Tabel 1)

Postur tubuh informan ketika mengalami PMM terlihat tidak jauh berbeda, kecuali pada informan $\mathrm{Z}$ yang ketika masih menderita PMM memiliki IMT sampai 9,34 dengan rincian berat badan $20,3 \mathrm{~kg}$ dan tinggi badan $147,4 \mathrm{~cm}$. Informan X memiliki postur tubuh yang termasuk kurus, yaitu berat badan 43,6 kg, tinggi badan $155,7 \mathrm{~cm}$, dan IMT 17,98. Informan Y yang sampai sekarang masih mengalami PMM memiliki IMT 16,27 dengan berat badan 46,64 $\mathrm{kg}$ dan tinggi badan $169,3 \mathrm{~cm}$. Pola makan tiap informan tiap harinya sesuai dengan PMM yang mereka alami. Untuk lebih jelasnya dapat dibaca pada kutipan di bawah ini jawaban informan mengenai pola makan dan pola kompensasi.

Informan X: “...gak tentu, bisa cuma 2 kali makan sehari, bisa 5 kali sehari makan hari-hari pada waktu itu... hampir gak makan nasi ya, makan nasi dan lauknya cuma kalo lagi diliatin orang rumah. Selebihnya aku ngemil banyak-banyak, trus gitu deh, dikluarin lagi... pernah dimuntahin, aku masukin jari ke kerongkongan... gak pake obat... Segera gue muntahin, setelah lambung terasa full."

Informan Y : "kebiasaan makan gue sekarang ya... dalam satu minggu ya gue recap rutinitasnya... jadi gue tuh jarang makan siang... kalo bangun tuh yang gue cari tuh rokok... tapi gue lebih suka kalo ada cemilan... misalnya roti-rotilah yang kecil-kecil atau kerupuk... dah itu cukup... terus gue berangkat ke kantor... di kantor juga yang gue cari tuh kopi... selama 5 hari kerja... seperti itu... pulang kantor kalo gue bisa makan ya cari makan... pancing pake minum air putih terus colok pake jari, biasanya biar kata perut gue udah kosong dan makanan dah semua keluar juga tetep aja ko gue pen keluarin cairan... iya biasanya gue minum obat pencahar..."

Informan $\mathrm{Z}$ : “...aku tuh dulu cuma minum air putih

Tabel 1. Karakteristik Informan Utama

\begin{tabular}{|c|c|c|c|c|c|c|c|c|}
\hline Informan & $\begin{array}{l}\text { Jenis } \\
\text { Kelamin }\end{array}$ & $\begin{array}{c}\text { Usia terjadi } \\
\text { PMM }\end{array}$ & Etnis & Status & $\begin{array}{c}\text { Pendidikan } \\
\text { Terakhir }\end{array}$ & Pekerjaan & Jenis PMM & Agama \\
\hline $\mathrm{X}$ & Perempuan & 17 & Melayu/Jawa & Menikah & $\mathrm{S} 1$ & Ibu rumah tangga & Bulimia Nervosa & Islam \\
\hline $\mathrm{Y}$ & Perempuan & 11 & Melayu/Jawa & Menikah & $\mathrm{S} 1$ & Karyawan swasta & Anoreksia-Bulimia Nervosa & Islam \\
\hline $\mathrm{Z}$ & Perempuan & 13 & Melayu/Jawa & Menikah & D3 & Karyawan swasta & Anoreksia Nervosa & Islam \\
\hline
\end{tabular}


sama makan buah. Aku gak makan nasi atau sayur gitu buah aja. Aku tuh paling seneng makan kuaci tiap hari satu bungkus sama yogurt. Minum sehari tuh satu-satusatu gitu, sore gak makan dan olahraga dari jam 2 sampai jam 5. Kalo pagi aku makannya ya sampe sekenyang-kenyangnya. Jarang banget siang aku minum air putih paling tadi jus buah itu dibuat es untuk diminum.... muntah enggak. Klo obat enggak juga."

Kebiasaan makan di keluarga informan X dibiasakan untuk makan bersama dengan seluruh anggota keluarga besar sampai X selesai SD. Selepas SD, X dibiasakan untuk memilih sendiri makanannya. Kebiasaan makan keluarga $\mathrm{Y}$ sendiri awalnya serupa dengan informan $\mathrm{X}$. Sejak orang tua $\mathrm{Y}$ bercerai kebiasaan makan $\mathrm{Y}$ berubah dari yang tadinya teratur menjadi tidak teratur. Sedangkan keluarga $\mathrm{Z}$ tidak mengharuskan anaknya untuk makan bersama. Semua informan lebih banyak mengkonsumsi camilan pada awalnya ketika masih kecil, kemudian dibiasakan untuk makan besar.

Acuan makan tiap informan didasarkan atas pemilihan makanan anggota keluarganya, kecuali pada informan X yang mengacu atas kebiasaan makan temantemannya. Tren makanan yang berlaku pada saat informan mengalami PMM tidak terlalu mempengaruhi kebiasaan makan informan.

Semua informan memiliki anggota keluarga lain yang juga memiliki masalah dengan berat badan. Informan Z memiliki kakak perempuan dengan masalah obesitas, informan Y memiliki garis keturunan gemuk dari ibunya, dan informan $\mathrm{Z}$ memiliki kakak perempuan yang bermasalah dengan kegemukan dan terlalu kurus. Hanya keluarga informan Y yang memiliki keturunan gemuk. Keluarga kedua informan lainnya tidak memiliki keturunan gemuk. Masalah keluarga yang dialami oleh informan biasanya berhubungan dengan orang tua mereka. Informan X memiliki rasa tidak suka kepada ayahnya karena perlakuan ayahnya yang telalu keras. Pola asuh keluarga $\mathrm{X}$ yang terlalu menuntun $\mathrm{X}$ untuk menjadi yang terbaik adalah salah satu hal yang membuat $X$ mulai melakukan PMM. Informan Y memiliki masalah karena orang tuanya yang bercerai dan ayahnya yang menikah kembali. Pola asuh keluarga Y juga penuh dengan disiplin sebelum orangtuanya bercerai. Setelah orang tuanya bercerai, informan Y tinggal sendiri dengan pembantunya atau menumpang di rumah temannya. Hanya beberapa kali informan $Y$ tinggal bersama dengan ayahnya. Informan $\mathrm{Z}$ memiliki masalah dengan ayahnya yang terlalu kaku dan kakak perempuannya. Kakak Z sering menakuti dan mengancam $\mathrm{Z}$ kalau $\mathrm{Z}$ tidak berhenti makan, $\mathrm{Z}$ akan menjadi gemuk seperti dirinya. $\mathrm{Z}$ diasuh dengan cukup baik oleh orang tuanya, tapi hubungan $Z$ dengan ayahnya memang kaku dan sulit untuk berkomunikasi.

Stress juga memiliki pengaruh bagi informan, tetapi hanya kepada kebiasaan makan informan X saja. X menyatakan dirinya mengatasi stress dengan makan. Hal ini tidak dirasakan oleh dua informan lain yang dapat mengatasi stressnya dengan tidak berhubungan dengan kebiasaan makan. Citra tubuh tiap informan terlihat terdistorsi, dimana mereka merasa diri mereka gemuk, padahal kenyataannnya mereka tidak gemuk. Konsep diri tiap informan juga lebih didasari oleh penampilan fisik. Pengaruh media massa dan rasa ketakutan menjadi dewasa tidak terlihat terlalu berpengaruh dengan kebiasaan PMM informan. Sementara keadan sosial ekonomi informan memang menunjukkan informan berasal dari keluarga dari golongan menengah ke atas.

Keadaan sosial budaya yang terlihat sebagai salah satu hal yang paling berpengaruh kepada kebiasaan PMM informan. Anggapan lingkungan informan yang negatif terhadap kegemukkan menjadi salah satu alasan informan melakukan PMM. Teman sebaya informan Y dan Z tidak terlalu mempengaruhi kebiasaan makan mereka. $\mathrm{Hal}$ ini berbeda dengan informan $\mathrm{X}$ yang kebiasaan makannya amat dipengaruhi oleh teman-temannya.

Dari ketiga informan hanya informan $\mathrm{Z}$ yang tidak pernah mengalami pelecehan seksual. Informan X pernah mengalami pelecehan seksual yang dilakukan oleh guru sekolahnya sendiri. Informan Y pernah mengalami pelecehan seksual yang dilakukan oleh teman ibunya. Terlihat peristiwa ini tidak terlalu mempengaruhi kebiasaan makan informan.

\section{Studi Kuantitatif}

Dari hasil perhitungan data yang diperoleh, jumlah responden yang mengalami kecenderungan PMM dengan menggunakan kuesioner dari Sarafino, ${ }^{10}$ adalah sebesar 138 orang dari $397(34,8 \%)$. Ada juga yang ternyata telah mengalami kecenderungan yang cukup serius yaitu sebesar 10 orang dari 397 (2,5\%). (Lihat Tabel 2)

Jumlah responden yang mengalami kecenderungan PMM anoreksia nervosa dengan menggunakan kuesioner dari Stice, ${ }^{9}$ adalah sebesar 46 orang dari 397 (11,6\%). (Lihat Tabel 3)

Sementara itu jumlah responden yang memiliki kecenderungan bulimia nervosa yaitu sebesar 107 orang dari $397(27 \%)$. (Lihat Tabel 4)

Ketika dilihat dari kecenderungan PMM menurut IMT terdapat sebanyak 13 responden (34,2\%) yang mengalami kecenderungan PMM memiliki IMT kurang dari normal, $99(36,7 \%)$ memiliki IMT tubuh yang normal dan $36(40,2 \%)$ memiliki IMT tubuh yang lebih dari normal. Nilai p-value yang diperoleh dari hasil analisis adalah 0,772 sehingga tidak terlihat adanya hubungan antara IMT dengan kecenderungan PMM pada penelitian ini. Hanya $1(2,6 \%)$ responden dengan kecenderungan anoreksia nervosa yang memiliki IMT kurang dari normal, 28 $(10,4 \%)$ responden memiliki IMT tubuh normal dan 17 
Tabel 2. Tabel Distribusi Responden Menurut Kecenderungan PMM

\begin{tabular}{lcl}
\hline Kecenderungan PPM & Frekuensi (n) & $\%$ \\
\hline Tidak & 249 & 62,7 \\
Kecenderungan & 138 & 34,8 \\
Ya & 10 & 2,5 \\
\hline Total & 397 & $\mathbf{1 0 0}$ \\
\hline
\end{tabular}

Tabel 3. Tabel Distribusi Responden Menurut Kecenderungan Anoreksia Nervosa

\begin{tabular}{lcc}
\hline Kecenderungan PPM & Frekuensi (n) & $\%$ \\
\hline Tidak & 351 & 88,4 \\
Kecenderungan & 46 & 11,6 \\
\hline Total & 397 & $\mathbf{1 0 0}$ \\
\hline
\end{tabular}

Tabel 4. Tabel Distribusi Responden Menurut Kecenderungan Bulimia Nervosa

\begin{tabular}{lcl}
\hline Kecenderungan PPM & Frekuensi (n) & $\%$ \\
\hline Tidak & 290 & 73 \\
Kecenderungan & 107 & 27 \\
\hline Total & 397 & 100 \\
\hline
\end{tabular}

$(19,1 \%)$ responden memiliki IMT lebih dari normal. Berdasarkan hasil analisa, terlihat adanya hubungan antara IMT dengan kecenderungan anoreksia nervosa dengan p-value 0,016. Responden dengan kecenderungan bulimia nervosa sebanyak $6(15,8 \%)$ responden memiliki IMT kurang dari normal, $73(27 \%)$ responden memiliki IMT normal, dan $28(31,5 \%)$ responden memiliki IMT lebih. Berdasarkan hasil analisis, dengan p-value 0,190 tidak terlihat adanya hubungan antara IMT dengan kecenderungan bulimia nervosa.

Gambaran kecenderungan PMM berdasarkan jenis kelamin menunjukkan data sebesar $83(38,6 \%)$ responden perempuan mengalami kecenderungan PMM, dan 65 $(35,7 \%)$ responden laki-laki mengalami kecenderungan PMM. Dari p-value yang diperoleh yaitu sebesar 0,774 terlihat tidak terdapat hubungan antara jenis kelamin dengan kecenderungan PMM. Sejumlah $30(14 \%)$ responden perempuan mengalami kecenderungan anoreksia nervosa dan $16(8,8 \%)$ laki-laki juga mengalami kecenderungan anoreksia nervosa. Nilai p-value yang diperoleh pada penelitian ini adalah 0,118 sehingga tidak terlihat adanya hubungan antara jenis kelamin dengan kecenderungan anoreksia nervosa. Responden dengan kecenderungan bulimia nervosa, $63(29,3 \%)$ responden adalah perempuan dan $44(24,2 \%)$ responden adalah laki-laki. Berdasarkan hasil analisis, dengan p-value 0,259 tidak terlihat adanya hubungan antara jenis kelamin dengan kecenderungan bulimia nervosa.

Gambaran distribusi responden yang memiliki kencenderungan PMM berdasarkan etnis. Dengan menggunakan hasil kecenderungan PMM terdapat sebanyak 144 responden $(37,6 \%)$ yang beretnis Melayu, 2 $(28,6 \%)$ responden yang beretnis Arab dan $2(33,3 \%)$ responden yang beretnis Cina mengalami kecenderungan PMM. Nilai p-value yang diperoleh dari hasil analisis adalah 0,980 sehingga tidak terlihat adanya hubungan antara Etnis dengan kecenderungan PMM pada penelitian ini. Terdapat $44(11,5 \%)$ responden dengan kecenderungan anoreksia nervosa yang beretnis Melayu, $1(14,3 \%)$ responden memiliki etnis Arab dan $1(16,7 \%)$ memiliki etnis Cina. Berdasarkan hasil analisa, $p$-value yang diperoleh 0,953 sehingga disimpulkan tidak adanya hubungan antara etnis dengan kecenderungan anoreksia nervosa pada penelitian ini. Responden dengan kecenderungan bulimia nervosa, $104(27,2 \%)$ diantaranya beretnis Melayu, $2(28,6 \%)$ beretnis Arab, dan $1(16,7 \%)$ responden beretnis Cina. Berdasarkan hasil analisis, dengan p-value 0,871 tidak terlihat adanya hubungan antara etnis dengan kecenderungan bulimia nervosa.

Setelah dilakukan analisis untuk melihat gambaran kecenderungan PMM berdasarkan usia diperoleh data sebesar $36(35 \%)$ responden yang berusia dibawah 14 tahun mengalami kecenderungan PMM, dan 112 (38,1\%) responden berusia 14 tahun ke atas mengalami kecenderungan PMM. Dari p-value yang diperoleh yaitu sebesar 0,480 , terlihat tidak terdapat hubungan antara usia dengan kecenderungan PMM. Ada $12(11,7 \%)$ responden berusia kurang dari 14 tahun mengalami kecenderungan anoreksia nervosa dan $16(8,8 \%)$ responden berusia 14 tahun ke atas juga mengalami kecenderungan anoreksia nervosa. Nilai p-value yang diperoleh pada penelitian ini adalah 1,000 sehingga tidak terlihat adanya hubungan antara usia dengan kecenderungan anoreksia nervosa. Responden dengan kecenderungan bulimia nervosa $23(22,3 \%)$ responden berusia kurang dari 14 tahun dan $84(28,6 \%)$ responden berusia 14 tahun ke atas. Berdasarkan hasil analisis, dengan p-value 0,247, tidak terlihat adanya hubungan antara usia dengan kecenderungan bulimia nervosa.

\section{Pembahasan \\ Kualitatif}

Dari hasil penelitian kualitatif, PMM informan telah sesuai dengan yang tertera pada literatur yang ada. Masing-masing informan mewakili beberapa tipe PMM. Informan X mewakili penderita bulimia nervosa, memiliki kebiasaan makan yang didahului dengan keinginan makan yang tinggi kemudian diikuti dengan tindakan makan secara berlebihan dan tanpa kendali, lalu muncul rasa sesal sehingga penderita melakukan tindakan kompensasi untuk mengatasi tindakan makannya. Informan $\mathrm{Y}$ 
mewakili penderita bulima-anoreksia nervosa, dimana perilaku makannya menahan diri untuk tidak makan dan kemudian ada beberapa episode dimana penderita akan merasa kehilangan kendali dan makan secara berlebih dan mengeluarkan kembali makanannya. Informan $\mathrm{Z}$ mewakili penderita anoreksia nervosa dengan kebiasaan makan yang menahan diri tidak makan setiap harinya.

Kebiasaan makan keluarga tiap informan terlihat amat mempengaruhi kebiasaan makan informan. Keluarga informan Y dan Z membebaskan kedua informan dalam memilih makanan sehingga ketika keduanya telah remaja dan dewasa, mereka merasa bebas dalam memilih makanan termasuk untuk tidak makan. Informan $\mathrm{X}$ yang diharuskan makan dengan tertib, menjadi memperhatikan makanannya dan ingin selalu menghabiskan makanannya. Hal ini juga didukung oleh pendapat $\mathrm{McCombs},{ }^{8}$ yang menyatakan kebiasaan makan anak dipengaruhi oleh juga oleh kebiasaan makan keluarga baik dari segi psikologis, maupu kebiasaan makan itu sendiri.

Pengaruh acuan makanan dan tren makanan yang berlaku terhadap kebiasaan makan informan sesuai dengan teori yang dikemukakan oleh Krummel, ${ }^{7}$ yang menyatakan acuan makanan remaja dipengaruhi antara lain oleh media massa, teman sebaya dan keluarga. Pengaruh teman sebaya sendiri bagi informan hanya terlihat paling menonjol pada informan X. Kemungkinan karena pergaulan informan X lebih luas dibanding dua informan lainnya.

Begitu juga dengan pengaruh sosial budaya terhadap kebiasaan makan informan terlihat memiliki pengaruh yang cukup besar pada tiap informan. Lingkungan ketiga informan yang menganggap negatif terhadap kegemukkan merupakan salah satu pendorong terjadinya PMM. Termasuk di dalamnya adalah media massa yang menampilakan sosok-sosok yang kurus sebagai sosok yang menarik. Walaupun pengaruh media massa ini tidak secara langsung.

Dengan adanya opini yang dibentuk media massa tersebut juga mempengaruhi konsep diri dan citra tubuh para informan. Konsep diri informan yang terlihat menilai diri berdasarkan penampilan dan citra tubuh informan yang menganggap dirinya gemuk padahal kenyataannya tidak. Kurangnya rasa percaya diri jika terlihat gemuk ini mungkin karena lingkungannya tidak mendukung keberadaan masalah kegemukkan.

Keberadaan anggota keluarga lain yang bermasalah dengan berat badan dan genetik terlihat memang mempengaruhi kebiasaan PMM para informan, tetapi masih belum jelas pada penelitian ini apakah hal ini memang dipengaruhi karena keturunan/biologis atau karena kebiasaan perilaku yang diterapkan di keluarga. Untuk mengetahui hal ini perlu dilakukan penelitian lain mengenai masalah ini.
Pola asuh keluarga dan terjadinya masalah keluarga merupakan salah satu faktor yang paling kuat dalam mempengaruhi masalah PMM ini. Hal ini terlihat pada hasil penelitian ini karena pada semua informan memiliki masalah keluarga yang cukup berat dan pola asuh keluarga yang cukup keras. Krummel, ${ }^{7}$ menyatakan pola asuh keluarga amat mempengaruhi kehidupan anak terutama diawal kehidupan.

Rasa stres yang dirasakan informan kini tidak terlalu mempengaruhi kebiasaan informan lagi. Tapi khusus informan X yang mengatasi masalah dengan makanan memang terlihat pengaruh stress terhadap kebiasaan makan. Pengaruh stress terhadap PMM memang belum jelas apakah stress sebagai penyebab atau akibat. Hasil penelitian ini juga belum dapat menunjukkan hal tersebut sehingga perlu dilakukan penelitian lain mengenai pengaruh stress terhadap PMM.

Pada penelitian ini diperoleh hasil bahwa para informan utama tidak merasa ketakutan dalam menjadi dewasa. Ketiganya merasa tidak terlalu memperhatikan mengenai bagaimana rasanya menjadi dewasa. Bahkan menurut informan X, dia merasa tidak sabar untuk menjadi dewasa. Hasil ini bertentangan dengan anggapan bahwa PMM dapat terjadi karena adanya rasa ketakutan penderita untuk menjadi dewasa. ${ }^{8} \mathrm{Hal}$ ini tidak terjadi pada informan utama penelitian ini mungkin karena informan tidak merasakan tekanan-tekanan seperti yang dikatakan McCombs tadi sehingga mereka tidak merasa ketakutan menjadi dewasa. Mungkin juga karena budaya yang berlaku di Indonesia tidak terlalu memberikan tekanan pada remaja seperti budaya dari Amerika. Awal terjadinya PMM pada informan sama seperti yang diajukan oleh teori dari McCombs, ${ }^{8}$ yaitu pada usia remaja antara 13-18 tahun.

Terjadinya pelecehan seksual tentunya akan meninggalkan kesan pada kehidupan penderita. Pada penelitian ini dua dari tiga informan utama pernah mengalami pelecehan seksual. Hanya informan $\mathrm{Z}$ yang tidak pernah mengalami pelecehan seksual. Dari kedua informan yang mengalami pelecehan seksual, hanya informan Y saja yang mengaku dididik dengan kebiasaan agama yang cukup ketat. Hal ini serupa dengan pendapat dari McCombs, ${ }^{8}$ yang melihat adanya hubungan antara seksualitas dengan PMM pada kelompok remaja dan dewasa muda. Masih belum jelas apakah pelecehan seksual ini memang memiliki hubungan dengan PMM atau tidak, sehingga masih perlu studi-studi lain untuk melihat hubungan antara keduanya.

Pekerjaan, etnis, jenis kelamin, dan sosial ekonomi informan terlihat memang berpengaruh dengan PMM, namun pada penelitian ini ketiga informan memiliki data yang hampir serupa pada keempat variabel tersebut sehingga masih perlu dilakukan penelitian lain untuk mengetahui lebih lanjut mengenai pengaruh pekerjaan, 
etnis, jenis kelamin, dan sosial ekonomi pada PMM.

\section{Kuantitatif}

Prevalensi kecenderungan PMM yang diperoleh pada penelitian ini terlihat jauh lebih tinggi dibandingkan prevalensi yang diperoleh oleh Lewinsohn dalam Thompson, ${ }^{11}$ di negara barat sebesar 4,4\% memiliki kecenderungan mengalami PMM. Hal ini menunjukkan ternyata kecenderungan PMM telah terjadi pada remaja Jakarta tanpa terdeteksi dan tanpa adanya perhatian.

Pada penelitian ini terlihat lebih banyak responden yang mengalami kecenderungan PMM memiliki IMT yang lebih tinggi dari pada mereka yang tidak mengalami PMM. Hal ini bertentangan dengan penelitian yang dilakukan oleh Kerruish, ${ }^{12}$ menemukan secara signifikan IMT penderita anoreksia nervosa memang lebih rendah dibandingkan normal. Begitu juga penelitian yang dilakukan oleh Grinspoon dalam Mayer, ${ }^{13}$ menunjukkan laju penambahan berat badan penderita anoreksia nervosa lebih lambat daripada normal. Perbedaan hasil ini kemungkinan disebabkan karena belum terlihatnya akibat dari PMM pada responden. Karena penelitian ini dilakukan pada responden yang belum pernah terdeteksi menderita PMM sehingga belum terlihat perubahan fisiologis yang terjadi.

Gambaran kecenderungan PMM dengan jenis kelamin menunjukkan perempuan lebih banyak yang mengalami kecenderungan PMM. Hasil tersebut sesuai dengan penelitian yang dilakukan oleh Patton, ${ }^{14}$ ditemukan laju perkembangan per 1000 orang tahun PMM pada perempuan adalah sebesar 21,8 dan pada laki-laki hanya 6,0. Thompson, 11 juga menambahkan hanya 1 dari 10 penderita yang berjenis kelamin laki-laki. Kemungkinan hal tersebut terjadi karena lebih tingginya tuntutan masyarakat terhadap perempuan untuk menjadi kurus. Baru pada beberapa tahun belakangan ini pria penderita PMM mulai mendapatkan perhatian. ${ }^{15}$

Penelitian Lee, ${ }^{4}$ menunjukkan bahwa $84,1 \%$ dari penderita PMM ini berasal dari etnis Cina, 7,9 \% berasal dari etnis Indian, dan 4,8\% berasal dari etnis Melayu/ Malaysia, walaupun perwakilan etnis Melayu amat kurang jika dibandingkan dengan populasi etnis lainnya. Menurut Grosvenor, ${ }^{16}$ PMM lebih sering terjadi pada etnis Kaukasian atau kulit putih, tetapi PMM sendiri dapat terjadi pada etnis-etnis lainnya. Hasil tersebut kurang lebih serupa dengan hasil penelitian ini. Perbedaan yang terjadi kemungkinan karena adanya perbedaan jumlah responden pada pengambilan sampel. Pada penelitian ini responden yang beretnis Melayu adalah 96,5\%, Arab $1,8 \%$, Cina $1,5 \%$ dan Kaukasia/kulit putih 0,3\%. Karena kurang meratanya etnis pada penelitian ini kemungkinan yang menjadi penyebab terjadinya perbedaan hasil penelitian dengan penelitian sebelumnya.

Rata-rata responden pada penelitian yang dilakukan oleh Lee, ${ }^{4}$ berusia 17,6 tahun. Hal ini sesuai dengan hasil penelitian ini yang menunjukkan sebagian besar responden berusia lebih dari 14 tahun. Rata-rata usia pada penelitian ini adalah 15 tahun yang juga tidak jauh berbeda dengan penelitian dari Lee. ${ }^{4} \mathrm{McCombs},{ }^{8}$ menyatakan rata-rata penderita anoreksia nervosa mulai menahan diri untuk tidak makan sejak usia 17 tahun dan beberapa data bahkan menunjukkan mulainya PMM adalah pada usia 13 sampai 18 tahun. Pernyataan ini didukung juga oleh Grosvenor, ${ }^{16}$ yang menyatakan PMM biasanya terjadi pada mereka ketika perkembangan fisik, psikologis, dan sisial sedang terjadi dengan pesat. Remaja lebih berisiko mengalami PMM mungkin disebabkan karena pada saat remaja, pencarian jati diri masih berlangsung dan jika tidak tertangani dengan baik remaja akan lebih mudah terjerumus dan melakukan perilaku-perilaku yang negatif seperti PMM.

\section{Kesimpulan}

Menurut persepsi informan yang mempengaruhi PMM antara lain adalah ada pengaruh dari teman sebaya, konflik keluarga, pola asuh keluarga, ketakutan menjadi seperti anggota keluarga lain yang juga bermasalah dengan berat badan. Informan menganggap alasan terjadinya PMM pada mereka adalah karena adanya anggota keluarga lain yang menakut-nakuti mereka sehingga mereka takut makan, terjadinya konflik keluarga yang berpengaruh pada kebiasan makan penderita, pola asuh keluarga yang terlalu menekan dan disiplin sehingga penderita mencari pelarian dari masalah utama mereka, dan pengaruh sosial budaya dalam membentuk gambaran bahwa tubuh yang kurus adalah tubuh yang menarik dan cantik. Berdasarkan penuturan informan, awal dari terjadinya PMM adalah ketika informan masih remaja. Ada informan yang merasa terganggu dengan perilakunya dan merasa ingin berhenti tapi ada juga yang merasa tidak ingin berhenti. Ada informan yang merasa orang lain penyebab utama dirinya mengalami PMM, tapi ada juga informan lainnya yang beranggapan dirinya sendiri yang memilih melakukan PMM.

Prevalensi kecenderungan PMM yang terjadi di Jakarta dengan menggunakan kuesioner dari Sarafino diperoleh sebesar 37,3\%. Prevalensi kecenderungan PMM di Jakarta dengan menggunakan kuesioner dari Stice diperoleh prevalensi kecenderungan mengalami anoreksia nervosa sebesar $11,6 \%$ dan prevalensi kecenderungan bulimia nervosa sebesar $27 \%$. Sebagian besar responden memiliki etnis Melayu (96,5\%), memiliki IMT tubuh yang normal $(68 \%)$, berjenis kelamin perempuan $(54,2 \%)$ dan berusia lebih dari 14 tahun $(74,1 \%)$.

Responden yang menunjukkan gejala kecenderungan PMM memiliki IMT tubuh yang lebih $(38,2 \%)$, beretnis 
Melayu (27,6\%), berjenis kelamin perempuan $(38,6 \%)$ dan berusia lebih dari 14 tahun $(38,1 \%)$. Responden yang menunjukkan gejala kecenderungan anoreksia nervosa memiliki IMT tubuh yang lebih $(19,1 \%)$, beretnis Cina $(16,7 \%)$, berjenis kelamin perempuan $(14 \%)$ dan berusia lebih dari 14 tahun $(11,6 \%)$. Responden yang menunjukkan gejala kecenderungan bulimia nervosa memiliki IMT tubuh yang lebih $(31,5 \%)$, beretnis Arab $(28,6 \%)$, berjenis kelamin perempuan $(29,3 \%)$ dan berusia lebih dari 14 tahun $(28,6 \%)$.

\section{Daftar Pustaka}

1. Logue, A.W.. The Psychology of Eating and Drinking. An Introduction. 2nd edition. 1998. New York: WH. Freeman \& Co.

2. Holmes, Leonard.,Ph.D.. What You Need to Know About Eating Disorders. www.mentalhealth.about.com. 2006. retrieved at 12032006

3. Sizer, Frances Sienkiewicz dan Eleanor Noss Whitney.. Nutrition Concept and Controversy. 1997. Printed in the USA: Wadsworth

4. Lee, H Y, E L Lee, P Pathy, Y H Chan. Anorexia Nervosa in Singapore: An Eight Year Retrospective Study.2005. Singapore Med J 2005; 46(6):275-281

5. Efron, Sonni. Eating Disorders on the Rise in Asia. www.healthyplace.com. 2006. retrieved at 29032006.

6. American Psychiatric Association. Diagnositic and Statistical Manual of Mental Disorders. 4th ed. 1994. Washington, DC:American Psyciatric Association
7. Krummel, Debra, MS, PhD, RD,, Penny M. Kris Etherton, MS, PhD, RD,. 1996. Nutrition in Women's Health. Maryland: Aspen Publication

8. McComb, Jacalyn J. Robert. Eating Disorder in Women and Children : Prevention Stress Management, and Treatment. 2001. Washington:CRC Press

9. Stice, Eric., Shireen L. Rizvi., Christy F. Telch.. Development and Validation of the Eating Disorder Diagnostic Scale:A Brief Self-Report Measure of Anorexia, Bulimia, and Binge-Eating Disorder. 2000. the American Psychological Association, Inc. 2000, Vol. 12, No. 2, 123-131 1040-3590/00/\$5.00 DOI: 10.1037//1040-3590.12.2.123

10. Sarafino, Edward P.. Health Psychology : Biopsychosocial Interactions. 1994. New York:John Wiley \& Sons, Inc.

11. Thompson, J. Kevin (ed). Handbook of Eating Disorders and Obesity. 2004. New Jersey:John Wiley \& sons,Inc

12. Kerruish, Kate P. dkk.. Body Composition in Adolescents with Anoreksia Nervosa. 2007. Am J Clin Nutr 2002;75:31-7

13. Mayer, Laurel. Body Composition \& Anorexia Nervosa: Does Physiology Explain Psycology? 2007. Am J Clin Nutr 2001; 73:851-2

14. Patton, G. C., R. Selzer, C. Coffey, J. B. Carlin, R. Wolfe,. Onset of Adolescent Eating Disorders: Population Based Cohort Study Over 3 Years. 1999. BMJ 1999;318:765-768

15. Bowman, barbara A dan Robert M russell. 2001. Present Knowledge in Nutrition 8th ed..Washington:ILSI

16. Grosvenor, Mary B., M.S., R.D., Lori A. Smolin, Ph.D.. 2002. Nutrition from Science to Life. New York:Harcourt College Pub. 